\title{
Registry of Outcome Measures (ROM); tools supporting review and selection of outcome measures (OMs) for studies and trials
}

\author{
Joanne Auld*, Michael Rose, Reza Seyedsadjadi \\ From 5th European Conference on Rare Diseases (ECRD 2010) \\ Krakow, Poland. 13-15 May 2010
}

\section{Background}

Selecting the right OMs for clinical trials/studies is critical to success. Unless it is done it can be a major barrier to translational research. The choice is best made by systematically reviewing existing OMs to identify suitable measures and inform decisions about adapting existing OMs or creating new ones. ROM helps this effort by offering information on an expanding number of potentially suitable OMs. We have added web-based tools to support the review and selection process.

\section{Method}

ROM incorporates:

1) a 'Tree of OMs' - allows the reviewer(s) to record OMs by category as being considered for a specific study or trial

2) a search engine that enables investigators to find potential OMs in ROM

3) a comparison table that displays information about multiple OMs to aid selection

4) a document in progress which will evolve into a Manual for the review and selection of OMs

These web based tools are easily accessible to collaborative groups. They can be open access so that all investigators can see work in progress, avoid duplication of effort, and contribute their views.

\section{Results}

These tools have led to the publication of more OM records in ROM and are appreciated by investigators.

\footnotetext{
* Correspondence: joanne.auld@iop.kcl.ac.uk

TREAT-NMD \& King's College London Room 91.23, 9th Floor, Ruskin Wing,

King's College Hospital, Denmark Hill, London SE5 9RS, UK
}

\section{Conclusion}

These new tools on http://www.researchrom.com will play an important part in helping translational research.

Published: 19 October 2010

doi:10.1186/1750-1172-5-S1-P12

Cite this article as: Auld et al:: Registry of Outcome Measures (ROM); tools supporting review and selection of outcome measures (OMs) for studies and trials. Orphanet Journal of Rare Diseases 2010 5(Suppl 1):P12.
Submit your next manuscript to BioMed Central and take full advantage of:

- Convenient online submission

- Thorough peer review

- No space constraints or color figure charges

- Immediate publication on acceptance

- Inclusion in PubMed, CAS, Scopus and Google Scholar

- Research which is freely available for redistribution

Submit your manuscript at www.biomedcentral.com/submit
Biomed Central 